\title{
Economic efficiency of biogas generation from food product waste
}

\author{
Viktor Koval ${ }^{1}$, Inesa Mikhno ${ }^{2}$, Gabriela Hajduga ${ }^{3,{ }^{*}}$, and Krzysztof Gaska \\ ${ }^{1}$ Department of Applied Economics, Odessa Institute of Trade and Economics of Kyiv National \\ University of Trade and Economics Odessa, 19 Kyoto Street, 02156 Kyiv, Ukraine \\ ${ }^{2}$ Institute of Water Problems and Land Reclamation NAAS, 37 Vasylkivska Street, 03022 Kyiv, \\ Ukraine. \\ ${ }^{3}$ Cracow University of Technology, Department of Environmental Engineering, Department of \\ Environmental Technologies, ul. Warszawska 24, 31-155 Kraków, Poland \\ ${ }^{4}$ Silesian University of Technology, Faculty of Energy and Environmental Engineering, Institute of \\ Water and Wastewater Engineering, ul. Stanisława Konarskiego 18, 44-100 Gliwice, Poland
}

\begin{abstract}
The issue of waste accumulation has become one of the global problems of humanity. In Ukraine, the main method of waste management is landfill depositing, which is unproductive and affects the ecosystem negatively. However, large landfill sites should be used to produce biogas, thereby reducing the environmental burden and the earned revenue should be used to introduce recycling and a gradual transition to a European waste management policy. The aim of our study was to investigate the state of waste recycling and the possibility of using waste landfills and food with lost consumptive qualities for biogas generation. To analyze the economic efficiency of the installation of biogas equipment in landfills and to investigate the current state of waste management in Ukraine. The research demonstrates that at present in Ukraine the problem of waste accumulation becomes actual. At the same time, the number of large waste landfills is increasing. It is proved that at landfills with an area of more than 50 hectares, the installation of biogas equipment is cost-effective, and the raw material can be distributed at the feed-in tariff, thus solving the energy problem.
\end{abstract}

\section{Introduction}

Currently, the problem of resource saving is becoming relevant in energy economy. One of the most promising sources of energy in recent years is the biogas produced as a result of decomposition of solid household waste organic part in anaerobic conditions that shortly arise after its burial. Biogas is considered as an alternative source of energy, but the different structural composition of the landfills and their specifics should be taken into account.

At present, there is growth of public awareness of the limited nature of environmental resources, which promotes the development and implementation of new economic models that can effectively manage resources and recycle them [1-3]. The amount of different wastes

\footnotetext{
* Corresponding author: gabriela.hajduga@gmail.com
} 
increases in relation to the speed of urbanization, but inappropriate treatment of wastes leads to health hazards and urban environment degradation $[1,4,5]$.

However, at the time of global demand for energy escalation, the importance of ecologically clean environment is also growing. Due to the extremely high energy potential, along with the safety and purity of its operation, a biogas plant, as one of the methods of utilization of food waste and energy complex, can be considered as a major investment in the future [5].

The development of biogas plants has a potential for growth and it can contribute to the development of the economy $[4,6]$, since biogas can reduce the greenhouse effect by diminishing the amount of carbon dioxide and methane generated during the process of waste biogas generation $[2,4,7]$.

\section{Materials and methods}

Theoretical and methodological basis of the research consists in general scientific and special methods. The general scientific methods such as monographic and dialectic are used for the process of collecting, systematizing and processing information for the research, as well as theoretical generalizations; the methods of synthesis and comparison are implemented for processing the statistical data necessary for assessing the state, dynamics and comparison of the studied indicators [8-10]. Analytical methods and analogical methods for studying waste management in supermarkets of different countries of the world were used. In addition to the general scientific methods, method of economic and mathematical modeling is applied [11]. The basis of the study is not only economic analysis, but also the consideration of the problem from the environmental point of view, which makes it possible to make this study systemic and complete. The information base of the study was legislative and regulatory acts of the European countries, analytical reviews and reports as well as statistical data on ecology and natural resources.

\section{Results}

An increase in the amount of waste in Ukraine and their irrational distribution and use have created huge mountains of garbage and trash in the territory of about ten percent of the country's total area. The dominant direction of energy use of biogas is the generation of electricity with the subsequent supply to the electricity grid. Over the last decade, biomethane production projects have been intensively developed, followed by pumped into the gas supply network.

The profitability of biogas production increases with the organic waste percentage in the structure of utility waste. The disadvantage of creating biogas production sites is the increase of self-inflammation risk and explosion hazard. Biogas produced at landfills is used for power generation mostly. At the Municipal solid waste- 5 landfill, $1 \mathrm{~m} .3$ of biogas can generate with $1.5 \mathrm{kWh}$ of electricity.

Currently, in Ukraine, the amount of waste is increasing due to its accumulation at landfills that could be used for biogas production (Table 1). From Table 1, we see there is not any growth in the rate of waste formation in some categories of municipal solid waste, this process occurs due to the economic crisis and inflation in the country, but we can observe constant accumulation of the total storage weight. 
Table 1. Waste generation according to the categories of materials that could be used for biogas production in thousands of tons [12].

\begin{tabular}{|c|c|c|c|c|c|c|c|c|c|c|c|}
\hline & \multicolumn{5}{|c|}{$\begin{array}{l}\text { Generated (thousands of tons per } \\
\text { year) }\end{array}$} & \multicolumn{3}{|c|}{$\begin{array}{l}\text { Utilized (thousands } \\
\text { of tons per year) }\end{array}$} & \multicolumn{3}{|c|}{\begin{tabular}{|c} 
Burnt to produce \\
energy \\
(thousands of tons \\
per year)
\end{tabular}} \\
\hline & 2012 & 2013 & 2014 & 2015 & 2016 & 2014 & 2015 & 2016 & 2014 & 2015 & 2016 \\
\hline $\begin{array}{c}\text { Animal } \\
\text { waste and } \\
\text { mixed } \\
\text { food } \\
\text { waste }\end{array}$ & 12850,0 & 9864,4 & 954,2 & 897,0 & 996,0 & 485,6 & 220,0 & 315,1 & 2,1 & 2,0 & 0,0 \\
\hline $\begin{array}{c}\text { Waste of } \\
\text { vegetable } \\
\text { origin }\end{array}$ & 267,5 & 287,2 & 9061,4 & 7742,3 & 8606,0 & 3020,4 & 2674,4 & 3158,4 & 396,9 & 462,0 & 392,3 \\
\hline $\begin{array}{l}\text { Animal } \\
\text { droppings, } \\
\text { urine and } \\
\text { manure }\end{array}$ & 5062,0 & 4736,1 & 4037,2 & 4938,0 & 4288,7 & 3082,0 & 3231,5 & 3146,9 & 0,0 & 0,0 & 0,0 \\
\hline $\begin{array}{c}\text { Domestic } \\
\text { household } \\
\text { waste and } \\
\text { similar } \\
\text { waste }\end{array}$ & 9713,3 & 10804 & 7125,7 & 6789,2 & 6946,2 & 3,8 & 4,0 & 6,5 & 152,8 & 256,4 & 257,3 \\
\hline
\end{tabular}

However, the industrial usage of biogas is possible after a landfill creation; it will become economically efficient if more than 1 million tons of solid domestic waste is reached. Since today, there is a large number of waste deposits with such characteristics on the territory of Ukraine, an interest in the task of their geographical and production identification for the purpose of cost-effective extraction of biogas is increasing (Figure 1).

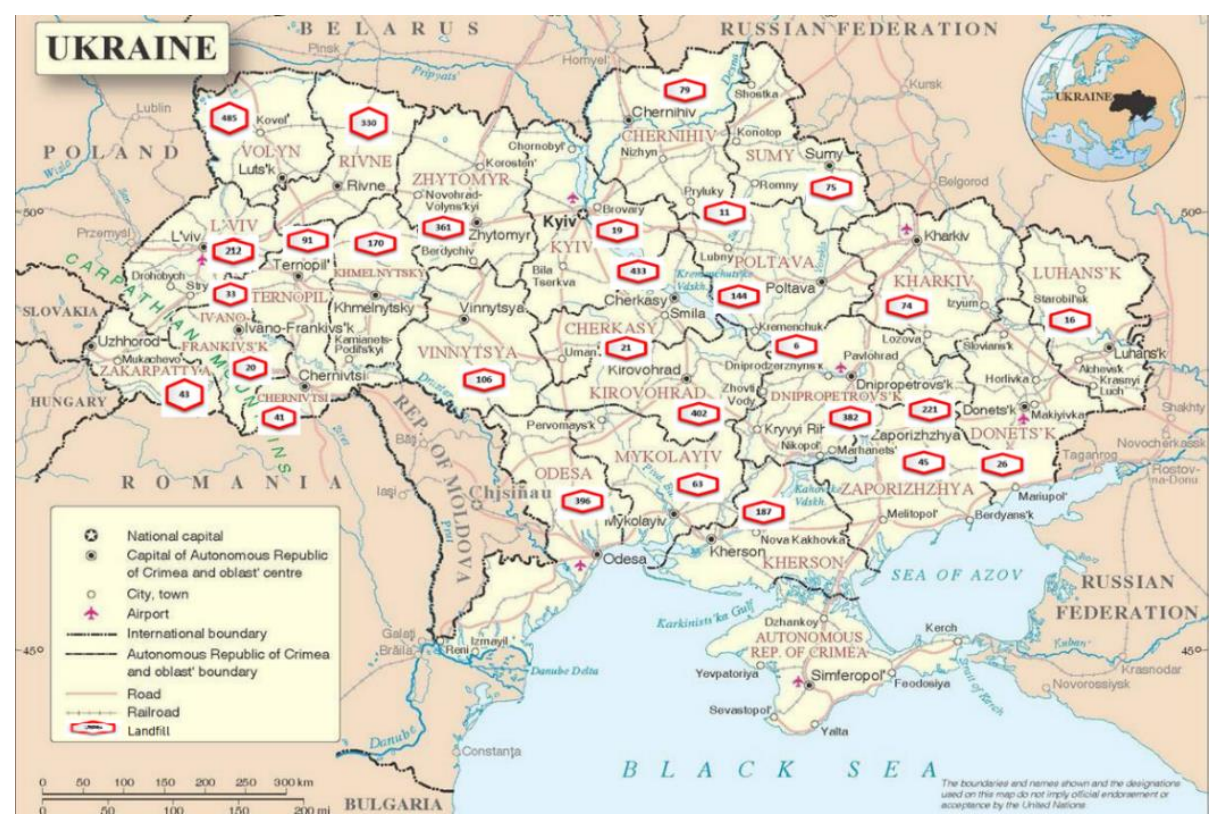

Fig. 1. Interactive map of waste disposal sites register in Ukraine as of 2018 [13]. 
During the process of creating a complex for biogas production, it is important to calculate the efficiency of its extraction from household waste for a specific waste landfill (Equation 1). The peculiarities of this method are the installation of the equipment on the landfill site, which could also have negative sides and affect the ecosystem around (it takes into account the indicators A, B) [8, 9-12]. Fractional waste treatment is considered to be more environmentally friend as it leads to reduce of residues amount (infinitesimal) and refusal of landfills as a form of waste storage as well as gradual processing of existing landfills [10-13]. However, in the current situation in Ukraine, it is expedient to install biogas plants until the process of recycling process throughout the country is established.

The efficiency of biogas extraction can be calculated according to the following formula:

$$
E=\frac{\sum_{i=1}^{n}\left(C_{i} \cdot Q_{i}\right)-\left(\sum_{j=1}^{m} A_{j}+\sum_{k=1}^{l} B_{k}\right)}{\sum_{i=1}^{n}\left(D_{i} \cdot Q_{i}\right)}
$$

$E$ - the efficiency of introducing biogas production by installing equipment at landfills for solid domestic waste, $C_{\mathrm{i}}$ - the rime cost of the products sold, $Q_{\mathrm{i}}$ - amount of sold products for a certain period of time (horsepower of equipment), $D$ - the price of biogas or energy unit sold, $A$ - the sum of expenses spent (m) on the amount of environmental protection measures and the restoration of the environment near the waste landfills, $B$ - the sum of compensation expenses spent (l) for the population living in the vicinity of the landfill's impact.

It should be noted, that the investment project with discounted net revenue must be higher than the contribution of equipment and costs associated with the activity of the complex biogas production (E $>$ NPV). For European countries, the E index should reach at least $2-3 \%$, while for countries with small planning horizons, that Ukraine belongs to it should be more than $15 \%$, which complicates the implementation of biogas collection systems, but taking into account the large raw material base and availability landfills more than 50 hectares, the process of biogas production becomes attractive.

With increasing landfill volume increases the amount of biogas production $(\mathrm{R})$.

$$
R=k \cdot \Delta s \cdot \Delta h
$$

$k$ - the index of biogas production growth with the increase of landfill waste area size of and height garbage mountain, $h$ - (from the zero mark - the bottom of the ditch).

It should be noted that with the growth and fall of the volume of landfill there is different effect on the nature of the indicators of the investment project of installing equipment in landfills solid household waste. It depends on the influence on their life cycle of external factors; therefore, it is advisable to apply the coefficient of elasticity in the stages of the life cycle $[5,11,14-18]$ to determine the degree of influence of external factors:

$$
\mathrm{KE}=\left|\frac{\frac{P(x) t^{-P}(x) t-1}{P_{(x) t-1}}}{\frac{X_{t}-X_{t-1}}{X_{t-1}}}\right|
$$

$K E$ - elasticity coefficient, $P_{(x) t}, P_{(\mathrm{x}) \mathrm{t}-1}-$ profitability indicator $\mathrm{x}$ enterprise activity at stages of the life cycle in the periods $\mathrm{t}$ and $\mathrm{t}-1[\%], \boldsymbol{X}, \boldsymbol{X}_{\mathrm{t}-1}-$ external factor of the environment of the enterprise operation in periods $\mathrm{t}$ and $\mathrm{t}-1[\%], P_{(x)}, X>0$.

According to the analysis the increase in landfill area of 10 hectares and garbage mountain's height of 10 meters, $R$ increases by 0.5 , that increases and profitability and proves 
the efficiency of large landfills and generation of $120 \mathrm{~m}^{3}$ gas from 1 ton of food waste can increase biogas production up to $200 \mathrm{~m}^{3}$ in mixed food waste.

Nowadays in Ukraine, there is growth in biofuel production by a method of crop products processing and by biogas production at landfills (Figure 2). At the garbage landfill \# 5 in the village of Pidhirtsi, Obukhiv district, Kyiv region, There is a line of five biogas engines with an installed capacity of $177 \mathrm{~kW}$ each, and the landfill gas company also extracts at Municipal solid waste- landfill in the villages of Gliboke (capacity $1.06 \mathrm{MW}$ ) and Rozhivka (capacity $-1.06 \mathrm{MW}$ ). The same biogas plants operate on landfills in the Zhytomyr and Mykolaiv regions. In a year, LLC LNK plans to launch a biogas recycling plant to produce electricity in Nikolaev. Biogas plants for power generation operate on two landfills of solid waste at Mariupol and at a municipal landfill near Vinnitsa. Lviv Yeast Plant, as well as Kyiv and Zapizhzhia Brewery plants receive biogas as a result of in-depth sewage treatment [17, 19].

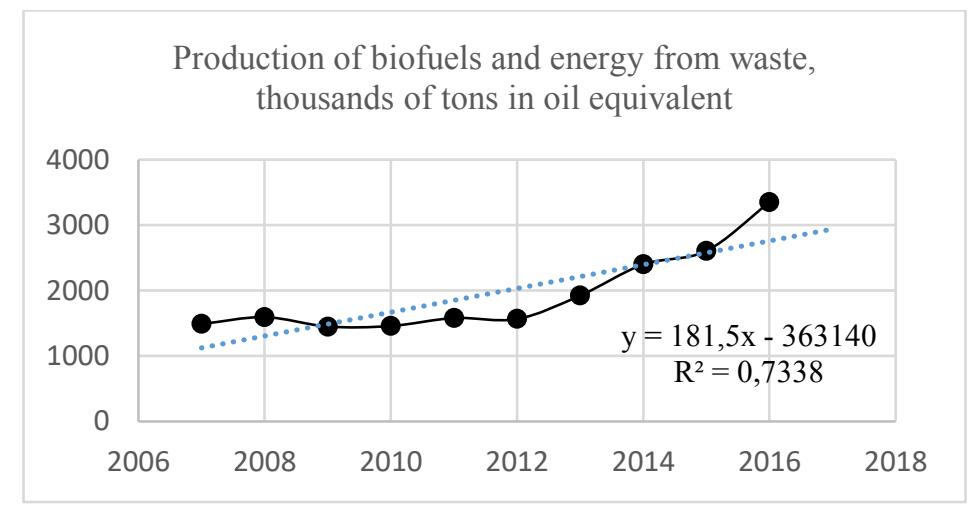

Fig. 2. Dynamics of production of biofuel and energy from waste in Ukraine for 2007-2016.

A large part of household waste is food. This component has a decomposition term of 1-6 months, and therefore they require rapid disposal. For example, in Germany, companies that have equipment for biogas production are involved in the recycling of food waste. Depending on the structure of food waste, from 1 ton of the food waste from $30 \mathrm{~m}^{3}$ to $800 \mathrm{~m}^{3}$ of biogas (lactose) can be obtained, which is an average of $130 \mathrm{~m}^{3}$ per 1 ton of food waste. From $1 \mathrm{~m}^{3}$ of biogas it is possible to produce $1.5-2.2 \mathrm{~kW}$ of electricity depending on the weight of methane. Biogas derived from biomass can be sold at gas stations for the needs of cars and agricultural machinery, or users of the gas network. According to the Law of Ukraine "On Electric Power", enterprises that produce electricity from alternative fuels can sell it, and the state must implement green tariffs purchasing the energy, which is 2.6 times more than wholesale tariffs [7, 20-22].

Currently, "green tariff" in Ukraine is set for 132 enterprises; seven of them produce biogas [3, 23-27]. According to the resolution of the Cabinet of Ministers of Ukraine dated on 02.02.2015, \#220, electricity is retailed to the population from March 1, 2017, at a price of $0.9 \mathrm{UAH}$ (green tariff is $1.1 \mathrm{UAH}$ that equals $\$ 0.04$ ) (up to $100 \mathrm{kWh}$ per month). Each year there are 6,9 million tons food waste (some of the waste is not recycled using different techniques), it is possible to get 1.2 billion $\mathrm{kW}$. electricity ( $\$ 0.05$ billion per year) [1, 27-29]. This indicator can be substantially increased in case of introduction of European legislation in relation to the consumption of out of products by population $[28,29]$.

In case of introduction of equipment for biogas production on the territories of large garbage landfills (more than 50 hectares), there are economic as well as social and environmental benefits (Figure 3). 


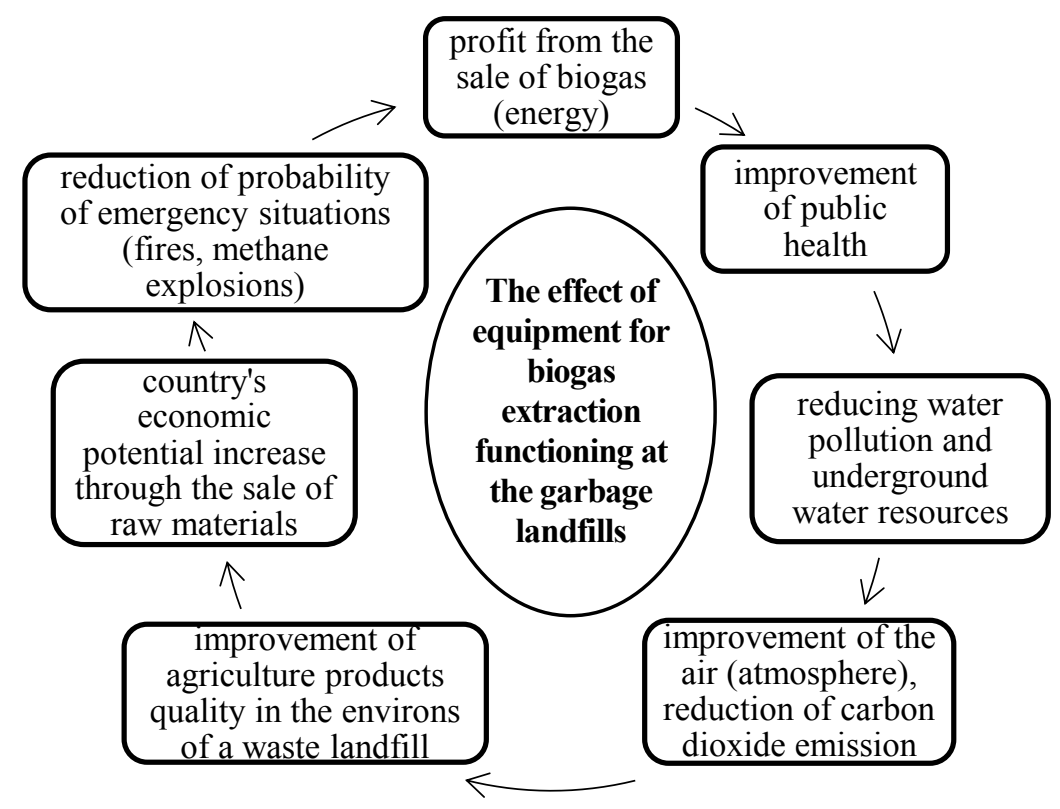

Fig. 3 The effect of equipment for biogas extraction functioning at the garbage landfills.

In Ukraine, there are not any regulations on food waste disposal that has not been merchandised, the life cycle of food products is increased by its processing and repackaging.

Figure 4 describes the life circle of food products in Ukraine, it depicts the desirable patterns of products processing, and that society should strive for. In particular, the role of entrepreneurs grows, as they are the basis for goods quality shaping process. Therefore, only a small amount of the food products is utilized.

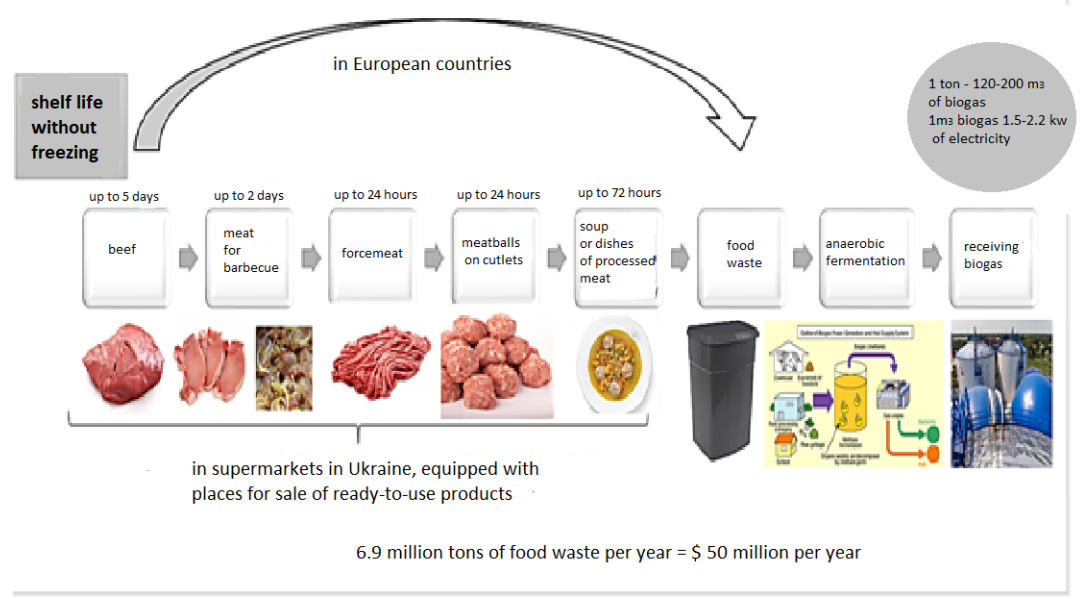

Fig. 4. Life circle of food products (that were not merchandised) and desirable patterns of products processing, on the example of beef (source: created by the authors)

In Germany, organic waste is recycled through recycling plants for biogas production. Currently, Germany has more than 100 waste recycling facilities, with the capacity of 18 million tons, although its annual production is 16 million tons. The government in Germany sets new tougher conditions for recycling for the society. Last year, a new law was 
passed on increasing the quota of supermarket processing of overdue products from 36 to $65 \%$, and starting from 1 January 2021 it would be $70 \%$ [21, 30-32]. In France, since 2016, it is prohibited for supermarkets to recycle of food products. There are high penalties for the violation of the regulation that equal 3750 euros. The food products reached $75 \%$ of their life circle, must be transferred to special charity food banks.

Creation of specially equipped centers for food processing, requires appropriate investments with the economic reliability justification and assessment of probabilistic nature of parameters of the environment $[15,33,34]$.

\section{Discussion}

In Ukraine, it is advisable to strengthen the system of control over food products sale and improve the system of penalties. These activities will improve the quality of products; create a system of discounts on goods, which life circle has reached $50 \%$. These changes can improve the work of transportation companies involved in the transport of waste to the points of garbage processing and introduce a waste sorting system. These actions would improve the quality of services in companies that sell food products, reduce the probability of poisoning among the population, and will lode to usage of overdue products for secondary production of biogas and change the existing waste management system. Taking into account the large number of landfills that operate in Ukraine, biogas equipment should be installed on the territories of landfills that there should be the installation of on their territory, the profitability of which is confirmed on similar sites in other countries of the world $[16,29]$. At present, such technology is already in use in Ukraine, however, it is not massive. A number of private companies processing biogas are processing less than $1 \%$ of waste that can be used for biogas production. We are invited to make adjustments to the state budget for allocating funds for the construction of biogas complexes at all large landfills in Ukraine at public funds, which would help solve the energy problem and reduce heating and electricity prices for the population, as only systemic actions on the territory of the country and control over the implementation of all necessary measures can solve the existing problem and effectively use internal resources.

\section{Conclusions and further research prospects}

Nowadays, the problem of non-utilized waste accumulation is increasing worldwide. At the same time, raw materials and energy problems remain urgent. Biogas production, using a waste disposal method, becomes more widespread and cost-effective at landfills with the area of over 50 hectares. Since the main method of waste management is landfill in Ukraine, it is recommended to install biogas equipment on the territory of all large waste landfills. These actions can solve the energy problem as well as other problems, and in general, it can increases the potential of the country and affects the ecosystem positively. It is proposed to improve the control system at the points of food product sale, and to send expired goods to waste recycling points for biogas production. In connection with the signing of the Association Agreement with the European Union it is proposed to use the experience of European countries in relation to the strategy of waste management.

\section{References}

1. N. M. Bocken, I. de Pauw, C. Bakker, B. van der Grinten, Journal of Industrial and Production Engineering 33, 303-308 (2006)

2. S. Begum, G. Anupoju, S. Sundergopal, S. Bhargava, Detritus 1, 75-82 (2018) 
3. Z. Kremljak, Annals of DAAAM \& Proceedings, 28 (2017)

4. L. Deng, Renewable and Sustainable Energy Reviews 70, 845-851 (2017)

5. M. Franchetti, J. Environ. Manage. 123, 42-48 (2013)

6. H. Sun-Kee, S. Hang-Sik, Japca. J. Air. Waste. Ma. 54, 2, 242-249 (2004)

7. J. Morrissey, J. Browne, Waste Manage. 24, 297-308 (2004)

8. P. Aragonés-Beltrána, J. A. Mendoza-Rocab, A. Bes-Piáa, M. García-Melónb, E. Parra-Ruizb, J. Hazard. Mater. 164, 1, 288-295 (2009)

9. G. Hajduga, A. Generowicz, E3S Web. Conf., 17 (2017)

10. K. A. Weitz, S. A. Thorneloe, S. R. Nishtala, S. Yarkosky, M. Zannes, Japca. J. Air. Waste. Ma. 52, 9, 1000-1011 (2002)

11. K. Gaska, A. Generowicz, Architecture, Civil Engineering, Environment 10, 117-126 (2017).

12. https://ukrstat.org.

13. https://ecomapa.gov.ua.

14. K. Gaska, A. J. Wandrasz, Waste Manage. 28, 973-985 (2008)

15. I. S. Mikhno, Archivarius 4, 49-54 (2015)

16. H. Hu, X. Li, A. Dung Nguyen, P. Kavan, Int. J. Environ. Res. Publ. Health 12, 7593-7614 (2015)

17. K. Govindan, S. Rajendran, J. P.Sarkis, P. Murugesan, J. Clean. Prod. 98, 1, 66-83 (2015)

18. O. Eriksson, M. Bisaillon, M. Haraldsson, J. Sundberg, J. Environ. Manage. 175, 33-39 (2016)

19. http://www.cewep.eu/2018/09/25/congress-2018/

20. A. Generowicz, K. Gaska, G. Hajduga, E3S Web. Conf., 44 (2018)

21. https:/eur-lex.europa.eu/eli/dir/2004/12/oj.

22. M. Marttunen, V. Belton, Eur. J. Oper. Res. 265, 1, 178-194 (2018)

23. Klang, P. A. Vikman, H. Btattebř, Conserv. Recycling 38, 317-334 (2003)

24. M. Garfe, S. Tondelli, A. Bonoli, Waste Manage. 29, 2729-2739 (2009)

25. E. den Boer, A. Jędrczak, Z. Kowalski, J. Kulczycka, R. Szpadt, Waste Manage. 30, 369-377 (2010)

26. http://aggeek.net/ru/technology/id/12-zanimatelnyh-faktov-o-biogaze-059

27. Generowicz, Pol. J. Environ. Stud. 23, 2, 57-63 (2014)

28. http://www.biteco-energy.com/vyhod-biogaza-iz-razlichnogo-syrya.

29. W. Balcerza, A. Generowicz, Z. Mucha, Pol. J. Environ. Stud. 23, 3, 983-987 (2014)

30. K. Jóźwiakowski, K. Mucha, A. Generowicz, Arch. Environ. Prot. 41, 3, 76-82 (2015)

31. Y. P. Li, G. H. Huang, J. Environ. Manage. 81, 188-209 (2006)

32. A. Generowicz, J. Kulczycka, Z. Kowalski, M. Banach, J. Environ. Manage. 92, 4, 1314-1320 (2011)

33. V. Koval, Y. Prymush, V. Popova, Baltic Journal of Economic Studies 3, 183-187 (2008)

34. M. Czop, $17^{\text {th }}$ International Multidisciplinary Scientific GeoConference SGEM 2017, 17, 52, 153-160 (2017) 